\title{
Residents`Perceptions of Economic Impacts of Tourism Development in Vrnjačka Banja, Serbia
}

\author{
Nataša Đorđevic ${ }^{1 *}$, and Snežana Milićević ${ }^{2}$ \\ ${ }^{1}$ University of Kragujevac, Faculty of Hotel Management and Tourism in Vrnjačka Banja, \\ Vojvođanska 5A, 36210 Vrnjačka Banja, Serbia \\ ${ }^{2}$ University of Kragujevac, Faculty of Hotel Management and Tourism in Vrnjačka Banja, \\ Vojvođanska 5A, 36210 Vrnjačka Banja, Serbia
}

\begin{abstract}
Research background: Tourism has become a favorable industry for many countries, considering the benefits it generates. The important part in reaching sustainability in tourism is to know how the local population perceives the effects of tourism. Tourism brings economic benefits, and on the other side it involves some economic costs, including government costs for infrastructure to better serve tourists, costs for local residents such as increased prices of goods and services, real estate, it generates seasonal unemployment, etc.

Purpose of the article: The aim of this study is to investigate how residents perceive the economic impacts of tourism development in Vrnjačka Banja.

Methods: Methods: The survey method was used to collect primary data. Data were processed by SPSS Statistics 23. The 14 defined statements of the economic impacts of tourism were subjected to Factor analysis. The internal consistency of the sample was carried out the Cronbach alpha coefficient.

Findings \& Value added: Results indicate that respondents perceive those impacts as more positive. Giving the fact that no research can be found in the scientific literature about how residents perceive the economic benefits and cost of tourism development in spa destinations, this study contributes to this field of study.

Keywords: tourism development, sustainability, economic impacts, local residents `perceptions, Vrnjačka Banja.
\end{abstract}

JEL Classification: $L 83, Z 30, Z 32$

*Corresponding author: natasa.djordjevic@kg.ac.rs 


\section{Introduction}

In 2018 international tourism generated exports of $\$ 1.7$ trillion, and it accounted for $10 \%$ of global GDP [2]. In 2019 international tourist arrivals continue to grow, but in 2020 due to COVID-19 pandemic crisis the number of tourists around the world dropped sharply in August by $79 \%$ [3]. Although tourism creates economic benefits for tourism destinations, after the introduction of sustainable tourism development it became important to investigate and present all of its positive and negative effects. The aim of the paper is to investigate how local population perceives the economic effects of tourism on the example of Vrnjačka Banja. Vrnjačka Banja is the most visited spa in Serbia and the most visited destination in Serbia after Belgrade. It is a small town tourism destination with 27.527 inhabitants, and a growing number of tourists in the last few years [4].

The basis of the economic significance of tourism is the tourists' consumption in the destinations they visit. Tourists spend the money they earned in the places of their permanent residence on accommodation, food, transportation, entertainment and other services and products in the destination [5]. As a result of tourist consumption, there are positive and negative economic effects in the tourist destination. A number of studies confirm that there is a positive correlation between the growth of the economy of destination and tourism [6,7]. Tourism has a significant effects on the growth of employment, quality of life of the local population, foreign exchange inflow, higher production of goods and services, and for other economic activities it has indirect benefits $[8,9]$. Tourism can encourage local entrepreneurship and attract more investment and business opportunities [10]. Tourism can improve infrastructure and suprastructure and public facilities in local destinations, all buttressed by the economic bounty derived from increased number of tourists [11]. On the other hand, the negative economic effects of tourism in the destination can be manifested through: pronounced seasonality of jobs, and thus job insecurity for the local workforce, a significant share of unskilled and low-paid jobs, destruction of traditional forms of employment, increase of superfluous imports, etc. [12]. Tourism also can cause local populations to suffer from higher living costs, higher prices of products as well as services necessary for everyday life, property prices and taxes [13].The host community is the key stakeholder for tourism development. Therefore, the perceptions and attitudes of the local community towards tourism are the key to create a competitive strategy and policy for tourism development at the local level, all that in order to reach sustainable development of the tourism destination. Numerous elements influence the perceptions of the local population regarding the development of tourism in the destination, such as socio-demographic characteristics of the population, a distance of their homes from the central tourist zone, their direct or indirect involvement in tourism, whether it is the peak season or off-season, number of tourists during the peak season, pressures on the natural and cultural attractions of the destination, etc. [8].

Aguilo' and Rossello' (2005) analyzed the perceptions of the local population in the Balearic Islands, and they find that they positively perceive the economic effects of tourism development, because it generates employment, attracts investment, and creates business chances for local residents, respectively. However, they are also aware of the negative economic effects, such as rising prices of products and services that are necessary for their daily lives [14]. Martín et al., (2020) measured perceptions of the local population regarding tourism in island Gran Canaria in Spain. The positive perceptions are observed according to economic growth and the creation of jobs, while the negative are observed in the containment of prices and the availability of affordable housing [15]. Akis et al. (1996) state that the perceptions of people living in Cyprus regarding tourism are negative due to local wage distribution changes replacing high-wage with low-wage jobs, and the tax liabilities increase [16]. 


\section{Methods}

The subject of the study is to investigate local population perceives the economic effects of tourism in Vrnjačka Banja. For data collection, a survey method was used. Data were processed by SPSS Statistics 23. Questionnaires were distributed in the form of a Google questionnaire in November 2020. A total 140 respondents are included by this research, as they stated that they live on the territory of Vrnjačka Banja municipality. Respondents had to answer on questions about their socio-demographic characteristics, and on the Likert scale from 1 to 5 ( $1=$ completely disagree, $5=$ completely agree $)$ they had to rate statements about economic effects of tourism in Vrnjačka Banja. Statements are based on earlier researches $[17,18,19,20,21,22]$, with small adaptation to conditions of tourism in Vrnjačka Banja. All defined statements were subjected to Factor analysis, while the internal consistency of the sample was carried out by the Cronbach alpha coefficient.

\section{Results and Discussions}

Out of 140 respondents who took part in this research 84 are male (60\%) and 56 are female respondents $(40 \%)$. Regarding the age of the respondents, more than a half of them have 20-30 years $(52.1 \%)$. Most of the respondents belongs to the group of respondents that are high school graduates $(32.9 \%)$ and have bachelor's degree $(32.9 \%)$, that are employed $(44.3 \%)$, have lived in this destination from 20 up to 30 years $(35.7 \%)$ and live near the town centre $(35.7 \%)$ (Table 1$)$.

Table 1. Socio-demographic characteristics of respondents

\begin{tabular}{|c|c|c|c|}
\hline & & Frequency & Percent \\
\hline \multirow[t]{2}{*}{ Gender } & Male & 84 & 60 \\
\hline & Female & 56 & 40 \\
\hline \multirow[t]{5}{*}{ Age } & $20-30$ & 73 & 52.1 \\
\hline & $31-40$ & 41 & 29.3 \\
\hline & $41-50$ & 15 & 10.7 \\
\hline & $51-60$ & 7 & 5.0 \\
\hline & $>60$ & 4 & 2.9 \\
\hline \multirow[t]{5}{*}{ Level of education } & High school graduate & 46 & 32.9 \\
\hline & Vocational degree & 13 & 9.3 \\
\hline & Bachelor's degree & 46 & 32.9 \\
\hline & Master degree & 27 & 19.3 \\
\hline & Doctoral degree & 8 & 5.7 \\
\hline \multirow[t]{4}{*}{ Professional status } & Unemployed & 42 & 30.0 \\
\hline & Employed & 62 & 44.3 \\
\hline & Student & 32 & 22.9 \\
\hline & Retired & 4 & 2.9 \\
\hline \multirow{4}{*}{$\begin{array}{l}\text { Part of destination } \\
\text { where residents live }\end{array}$} & In the centre & 27 & 19.3 \\
\hline & Near the centre & 50 & 35.7 \\
\hline & On the outskirts & 24 & 17.1 \\
\hline & In the nearby village & 39 & 27.9 \\
\hline \multirow{4}{*}{$\begin{array}{l}\text { Length of residency in } \\
\text { Vrnjačka Banja }\end{array}$} & up to 5 years & 35 & 25.0 \\
\hline & $5-10$ & 9 & 6.4 \\
\hline & $10-20$ & 23 & 16.4 \\
\hline & $20-30$ & 50 & 35.7 \\
\hline
\end{tabular}




\begin{tabular}{|l|l|c|c|}
\hline & $30-40$ & 20 & 14.3 \\
\cline { 2 - 4 } & $>40$ years & 3 & 2.1 \\
\hline
\end{tabular}

Source: Authors, based on research

The 14 items of the positive and negative economic impacts of tourism were subjected to Factor analysis using SPSS. The Kaiser-Meyer-Oklin value is .77, and the results of Bartlett's Test of Sphericity indicate that statistical significance is reached (sig. $=.000)$ (Table 2).

Table 2. KMO and Bartlett's Test

\begin{tabular}{|l|l|r|}
\hline Kaiser-Meyer-Olkin Measure of Sampling Adequacy. & .772 \\
\hline Bartlett's Test of Sphericity & Approx. Chi-Square & 1160.251 \\
\cline { 2 - 3 } & df & 91 \\
\cline { 2 - 3 } & Sig. & .000 \\
\hline
\end{tabular}

Source: Authors, based on research

The results of factor analysis revealed that there are three factors eigenvalues exceeding $1(33.5 \%, 24.1 \%$, and $10.5 \%$ of the variance). According to the Scree plot, there is a break after the second factor, which is why two factors are used for further analysis, explaining $57.6 \%$ of the variance. Oblimin rotation is used for better interpretation and both factors showed a strong loading. Positive economic impacts items loading strongly on Factor 2, and negative economic impacts items loading strongly on Factor 1. Therefore, the results of the Factor analysis support the use of the positive economic impacts items and negative economic impacts items as separate scales (Table 3). Between Factor 1 and Factor 2 there is a weak negative correlation $(\mathrm{r}=-0.131)$.

Table 3. Rotated factor loadings and communalities, Oblimin rotation

\begin{tabular}{|l|c|c|c|}
\hline \multirow{2}{*}{ Variable } & \multicolumn{2}{|c|}{ Factor } & \multirow{2}{*}{ Communality } \\
\cline { 2 - 3 } & $\mathbf{1}$ & $\mathbf{2}$ & \\
\hline $\begin{array}{l}\text { Residents and small enterprises have economic } \\
\text { benefits from tourism in destination }\end{array}$ & -.013 & $\mathbf{. 6 6 7}$ & .447 \\
\hline $\begin{array}{l}\text { Tourism makes more employment chances for local } \\
\text { people }\end{array}$ & .042 & $\mathbf{. 7 5 0}$ & .555 \\
\hline Tourism increases life standard of local people & .000 & $\mathbf{. 7 9 9}$ & .638 \\
\hline Tourism leads to more investment and spending & .082 & $\mathbf{. 8 6 7}$ & .740 \\
\hline $\begin{array}{l}\text { Tourism brings benefits for many industries in the } \\
\text { destination, not just for tourism industries }\end{array}$ & .169 & $\mathbf{. 7 5 8}$ & .570 \\
\hline Tourism leads to better infrastructure in destination & -.145 & $\mathbf{. 4 4 0}$ & .231 \\
\hline Tourism boosts incomes of my family & -.110 & $\mathbf{. 5 9 8}$ & .387 \\
\hline $\begin{array}{l}\text { Tourism affects the growth of prices of goods and } \\
\text { services in the destination }\end{array}$ & $\mathbf{. 7 9 9}$ & .003 & .637 \\
\hline Tourism affects the growth of prices of real estate & $\mathbf{. 8 3 3}$ & .081 & .684 \\
\hline Tourism cause seasonal unemployment & $\mathbf{. 8 2 6}$ & .079 & .671 \\
\hline $\begin{array}{l}\text { Tourism influence the growth of the living costs in the } \\
\text { destination }\end{array}$ & $\mathbf{. 7 4 4}$ & -.013 & .557 \\
\hline $\begin{array}{l}\text { A small number of local population have economic } \\
\text { benefit of tourism }\end{array}$ & $\mathbf{. 8 1 1}$ & .024 & .652 \\
\hline
\end{tabular}




\begin{tabular}{|l|c|c|c|}
\hline Local population have low-paid jobs in tourism & $\mathbf{. 7 5 4}$ & -.116 & .604 \\
\hline $\begin{array}{l}\text { There is no economic equality between residents due } \\
\text { to the tourism }\end{array}$ & $\mathbf{. 8 2 1}$ & -.080 & .698 \\
\hline \% of variance explained & $33.5 \%$ & $24.1 \%$ & \\
\hline
\end{tabular}

Source: Authors, based on research

The condition of internal consistency is achieved, and it is tested by using the Cronbach alpha coefficient. For the statements that describe positive economic impacts the Cronbach alpha coefficient is 0.813 and for the negative ones is 0.905 (Table 4).

Table 4. Cronbach's Alpha

\begin{tabular}{|l|c|c|}
\hline & Results & N of Items \\
\hline Positive economic impacts & 0.813 & 7 \\
\hline Negative economic impacts & 0.905 & 7 \\
\hline All variables & 0.769 & 14 \\
\hline
\end{tabular}

Source: Authors, based on research

The results of the survey indicate that residents have the most positive perceptions toward a statement that Tourism brings benefits for many industries in the destination, not just for tourism industries $(\mathrm{M}=4.5)$. Respondents expressed a high level of agreement that Tourism makes more employment chances for local people, increases life standard of local people and leads to more investment and spending by rating all three statements with an equal mean score $(\mathrm{M}=4.2)$. Also, respondents highly agree that Residents and small enterprises have economic benefits from tourism in destination $(\mathrm{M}=4.1)$. Residents who completed the survey agreed that tourism boosts their family incomes, by giving the total mean score for this impact of 3.7. Respondents do not firmly believe that Tourism leads to better infrastructure in destination, as this statement received the lowest mean score $(\mathrm{M}=3.4)$ (Table 5).

Table 5. Positive economic impacts of tourism in Vrnjačka Banja

\begin{tabular}{|l|c|c|c|}
\hline & N & Mean & $\begin{array}{c}\text { Std. } \\
\text { Deviation }\end{array}$ \\
\hline $\begin{array}{l}\text { Residents and small enterprises have economic benefits } \\
\text { from tourism in destination }\end{array}$ & 140 & 4.1000 & 1.02697 \\
\hline Tourism makes more employment chances for local people & 140 & 4.2500 & 1.09364 \\
\hline Tourism increases life standard of local people & 140 & 4.2357 & .91046 \\
\hline Tourism leads to more investment and spending & 140 & 4.2429 & .99547 \\
\hline $\begin{array}{l}\text { Tourism brings benefits for many industries in the } \\
\text { destination, not just for tourism industries }\end{array}$ & 140 & 4.5500 & .82519 \\
\hline Tourism leads to better infrastructure in destination & 140 & 3.4429 & 1.28786 \\
\hline Tourism boosts incomes of my family & 140 & 3.7357 & 1.14182 \\
\hline
\end{tabular}

Source: Authors, based on research

As the most negative impact respondents rated statement that Tourism affects the growth of prices of goods and services in the destination $(\mathrm{M}=3.2)$ and that it affects the growth of prices of real estate $(\mathrm{M}=3.0)$. Respondents largely disagree towards negative economic effects, considering that they rated other five statements with a mean score below 3: There is no economic equality between residents due to the tourism $(\mathrm{M}=2.8)$, Tourism influence the growth of the living costs in the destination $(\mathrm{M}=2.7)$, Tourism cause seasonal 
unemployment $(\mathrm{M}=2.5)$, A small number of local population have economic benefit of tourism $(\mathrm{M}=2.3)$, Local population have low-paid jobs in tourism $(\mathrm{M}=2.2)$ (Table 6).

Table 6. Negative economic impacts of tourism in Vrnjačka Banja

\begin{tabular}{|l|c|c|c|}
\hline & N & Mean & $\begin{array}{c}\text { Std. } \\
\text { Deviation }\end{array}$ \\
\hline $\begin{array}{l}\text { Tourism affects the growth of prices of goods and services } \\
\text { in the destination }\end{array}$ & 140 & 3.1643 & 1.42743 \\
\hline Tourism affects the growth of prices of real estate & 140 & 3.0214 & 1.40127 \\
\hline Tourism cause seasonal unemployment & 140 & 2.5500 & 1.26562 \\
\hline $\begin{array}{l}\text { Tourism influence the growth of the living costs in the } \\
\text { destination }\end{array}$ & 140 & 2.6643 & 1.28416 \\
\hline $\begin{array}{l}\text { A small number of local population have economic benefit } \\
\text { of tourism }\end{array}$ & 140 & 2.3500 & 1.17483 \\
\hline $\begin{array}{l}\text { Local population have low-paid jobs in tourism } \\
\begin{array}{l}\text { There is no economic equality between residents due to the } \\
\text { tourism }\end{array}\end{array}$ & 140 & 2.2357 & 1.08363 \\
\hline
\end{tabular}

Source: Authors, based on research

The mean score for all defined positive economic effects $(\mathrm{M}=4.1)$ is higher compared to the mean score for the negative ones $(\mathrm{M}=2.7)$. This indicates that the local population who took the part in this study perceives the economic effects of tourism in Vrnjačka Banja in a positive way (Table 7).

Table 7. Descriptive Statistics of Factors

\begin{tabular}{|l|c|c|c|c|c|}
\hline & Mean & Minimum & Maximum & Variance & N of Items \\
\hline Positive impacts & 4.080 & 3.443 & 4.550 & .138 & 7 \\
\hline Negative impacts & 2.680 & 2.236 & 3.164 & .114 & 7 \\
\hline
\end{tabular}

Source: Authors, based on research

\section{Conclusion}

Positive economic impacts of tourism have been in the focus of tourism development, and this led to the mass tourism. After the negative impacts of mass tourism arose, the concept of sustainability became a necessity and a trend in the tourism market. According to the sustainability concept the impacts of tourism in a destination should be observed and measured. One way to this is to measure local residents' perceptions of it, which is important considering that they are exposed to those impacts and face them by living in a tourism destination.

The results of this research show that there is positive perception of the economic impacts of tourism among residents of Vrnjačka Banja. As the most positive impact local residents rated the statement that Tourism benefits other than just tourism industries in our community, while the most negative one is that Tourism affects the growth of prices of goods and services in the destination.

The research contributes to this field of study, considering that there are no researches about residents ' perceptions of the economic impacts of tourism in spa destinations. Future researches should focus on finding a significant difference in residents' perception of the 
economic impacts of tourism depending on the level of their participation in tourism development.

Acknowledgment - The manuscript is a part of research within the project no. III 46006 - Sustainable agriculture and rural development in the function of accomplishing strategic objectives of the Republic of Serbia in the Danube region, financed by the Ministry of Education, Science and Technological Development of the Republic of Serbia.

\section{References}

1. UNWTO (2019). Tourism Highlights. Retrieved from: https://www.eunwto.org/doi/pdf/10.18111/9789284421152

2. UNWTO (2020). World Tourism Barometar. Retrieved from: https://webunwto.s3.eu-west1.amazonaws.com/s3fspublic/202001/UNWTO_Barom20_01_January_excerpt_0. pdf

3. UNWTO (2020). International Tourism Down $70 \%$ as Travel Restrictions Impact All Regions. Retrieved from : https://www.unwto.org/taxonomy/term/347

4. Đorđević, N., Milićević, S. (2020). Perceptions of environmental impacts of tourism: A case study of Vrnjačka Banja. eds: D. Cvijanović, A., Ivolga, L. M. Colarič-Jakše, A. J. Vasile, N. Dimitrov, A. Lemmetyinen, P. Ružić, C. Amdreeski, D. Gnjatović, A. Mićović, M. Leković, D. Dimitrovski, The Fifth International Scientific Conference „,Tourism in function of development of the Republic of Serbia: Tourism and Rural Development" September 3-5th, 2020, Vrnjačka Banja Thematic proceedings 1, 147-163.

5. Milićević, S., Štetić, S. (2017). Menadžment u turizmu [Tourism Management], University of Kragujevac Faculty of Hotel Management and Tourism in Vrnjačka Banja.

6. Hye QMA, Khan REA (2012). Tourism-led growth hypothesis: A case study of Pakistan. Asia PacificJournal of Tourism Research, 18(4), 303-313.

7. Sequeira TN., Nunes, PM (2008). Does tourism influence economic growth? A dynamic panel data approach. Applied Economics 40. 2431-2441.

8. Milićević, S., Podovac, M., Đorđević, N. (2020). Local residents' attitudes towards tourism events: A case study of the Carnival of Vrnjci, Serbia. Ekonomika, 66(2), 75-91.

9. Cannonier, C., Burke, M.G. (2019). The economic growth impact of tourism in Small Island Developing States-evidence from the Caribbean. Tourism Economics, 25(1), 85-108.

10. López, M. F. B., Virto, N. R., Manzano, J. A., Miranda, J. G. M. (2018). Residents' attitude as determinant of tourism sustainability: The case of Trujillo. Journal of Hospitality and Tourism Management, 35, 36-45.

11. Deery, M., Jago, L., Fredline, L. (2012). Rethinking social impacts of tourism research: A new research agenda. Tourism Management, 33(1), 64-73.

12. Kostić, M., Milićević, S. (2018), Ekomenadžment turističke destinacije [Ecomanagement of a Tourism Destination], University of Kragujevac Faculty of Hotel Management and Tourism in Vrnjačka Banja.

13. Látková, P., Vogt, C. A. (2012). Residents' attitudes toward existing and future tourism development in rural communities. Journal of Travel Research, 51(1), 5067. 
14. Aguilo' E, Rossello' J (2005) Host community perceptions: a cluster analysis. Annals of Tourism Research, 32(4) 925-941.

15. Martín, J.C., Moreira, P., Román, C. (2020). A hybrid-fuzzy segmentation analysis of residents' perception towards tourism in Gran Canaria. Tourism Economics, 26(7), 1282-1304.

16. Akis S, Peristianis N, Warner, J. (1996). Residents' attitudes to tourism development: the case of Cyprus. Tourism Management, 17(7), 481-494.

17. Aref, F., Redzuan, M., Gill, S. S. (2009). Community perceptions toward economic and environmental impacts of tourism on local communities. Asian Social Science, 5(7), 130-137.

18. Alrwajfah, M. M., Almeida-García, F., Cortés-Macías, R. (2019). Residents' perceptions and satisfaction toward tourism development: A case study of Petra Region, Jordan. Sustainability, 11(7), 1907.

19. Mohammadi, M., Khalifah, Z., Hosseini, H. (2010). Local people perceptions toward social, economic and environmental impacts of tourism in Kermanshah (Iran). Asian Social Science, 6(11), 220.

20. Sirakaya, E., Teye, V., Sönmez, S. (2002). Understanding residents' support for tourism development in the central region of Ghana. Journal of Travel Research, 41(1), 57-67.

21. Yu, C. P., Chancellor, H. C., Cole, S. T. (2011). Measuring residents' attitudes toward sustainable tourism: A reexamination of the sustainable tourism attitude scale. Journal of Travel Research, 50(1), 57-63.

22. Vieira, I., Rodrigues, A., Fernandes, D., \& Pires, C. (2016). The role of local government management of tourism in fostering residents' support to sustainable tourism development: evidence from a Portuguese historic town. International Journal of Tourism Policy, 6(2), 109-135. 